\title{
Toxicity of Pb contaminated soils to the oribatid mite Platynothrus peltifer
}

\author{
Wei Luo • Rudo A. Verweij • Cornelis A. M. van Gestel
}

Accepted: 26 February 2015/Published online: 11 March 2015

(c) The Author(s) 2015. This article is published with open access at Springerlink.com

\begin{abstract}
To understand the toxicity of $\mathrm{Pb}$-polluted shooting fields, oribatid mites Platynothrus peltifer were exposed to shooting field soils containing 47-2398 mg Pb/ kg dry weight (DW) and having $\mathrm{pH}_{\mathrm{CaCl}_{2}} 3.2-6.8$ and 3.8$13 \%$ organic matter $(\mathrm{OM})$. Exposures also included artificial soils with different $\mathrm{pH}$ and $\mathrm{OM}$ contents as well as two natural soils used as controls. Exposures lasted for 2 (acute) and 12 weeks (chronic). Survival, reproduction and uptake of $\mathrm{Pb}$ in the mites were related to total, water-extractable and $0.01 \mathrm{M} \mathrm{CaCl}_{2}$-extractable and porewater $\mathrm{Pb}$ concentrations as well as soil characteristics. After both the acute and chronic exposures, adult survival was not significantly affected, while upon chronic exposure reproduction was remarkably reduced in the acidic forest soils with $\mathrm{Pb}$ concentrations $\geq 2153 \mathrm{mg} / \mathrm{kg}$ DW and $\mathrm{pH}_{\mathrm{CaCl}_{2}} \leq 3.5$. P. peltifer juvenile numbers were significantly negatively and internal $\mathrm{Pb}$ concentrations in the mites were significantly positively related with total, extractable and porewater $\mathrm{Pb}$ concentrations. This study shows that $P$. peltifer is not very sensitive to $\mathrm{Pb}$ and therefore may not be a suitable indicator of Pb-polluted soils.
\end{abstract}

Keywords Lead - Exposure - Toxicity - Oribatid mites · Bioaccumulation

\section{W. Luo}

State Key Lab of Urban and Regional Ecology, Research Center for Eco-Environmental Sciences, Chinese Academy of Sciences, Beijing 100085, China

W. Luo · R. A. Verweij · C. A. M. van Gestel ( $₫)$ Department of Ecological Science, Faculty of Earth and Life Sciences, VU University, De Boelelaan 1085, 1081 HV Amsterdam, The Netherlands

e-mail: kees.van.gestel@vu.nl

\section{Introduction}

Lead $(\mathrm{Pb})$ is ranked as the number two priority hazardous substance by the US EPA (Chen et al. 2002). Annual deposition of metallic lead at shooting ranges has reached 6000 tons in the Netherlands, Finland, Denmark, Canada, England and USA (Manninen and Tanskanen 1993; Scheuhammer and Norris 1995). In recent years, shooting ranges are under increasing scrutiny as a potentially significant source of lead contamination (Chen et al. 2002; Ming et al. 2012; Murray et al. 1997; Rooney et al. 1999).

Routine practices for investigating the exposure and risk of $\mathrm{Pb}$-contaminated sites involve determining total $\mathrm{Pb}$ concentrations in soils. However, total $\mathrm{Pb}$ concentrations may not predict adverse effects accurately (Ming et al. 2012; Peijnenburg et al. 1999), because exposure expressed as total $\mathrm{Pb}$ does not consider the effect of soil-modifying factors like $\mathrm{pH}, \mathrm{OM}$ content and cation exchange capacity on $\mathrm{Pb}$ bioavailability (Allen 2002; Lanno 2003). Furthermore, a successful assessment of metal polluted soils also requires a battery of biological exposure tests including different soil invertebrates representative of the soil ecosystem (Hopkin 1989).

Among the soil invertebrates, oribatid mites are the world's most numerous arthropods. They play important roles in the forming of soil structure, decomposition processes and detrital food-webs (Crossley 1977; Krantz and Walter 2009; Lebrun 1979). Platynothrus peltifer is a representative of the oribatid mites (Van Gestel and Doornekamp 1998). However, up to now, it has not been used so often in the assessment of metal-contaminated sites and little is known about its sensitivity to metal-polluted soils (Van Gestel and Doornekamp 1998; Van Gestel et al. 1995).

Here, the main purpose of this study is to assess sensitivity of $P$. peltifer after being acutely and chronically 
exposed to different field-contaminated soils from a shooting range. More specific aims were to determine survival and reproduction of $P$. peltifer following exposure to shooting range soils and relate effects to $\mathrm{Pb}$ uptake in the animals as well as to total and available concentrations in the soil and to soil properties. Recently, we have studied $\mathrm{Pb}$ bioaccumulation and toxicity to earthworms (Luo et al. 2014c), springtails (Luo et al. 2014a) and enchytraeids (Luo et al. 2014b) exposed to shooting field soils. We hypothesized that these shooting field soils would also be toxic to $P$. peltifer. We also hypothesized that toxicity would be related to the bioavailable $\mathrm{Pb}$ concentrations in soil, as reflected by $\mathrm{Pb}$ uptake in the animals. In addition, we expected toxicity to increase with increasing exposure time and to be affected by soil properties, with soil $\mathrm{pH}$ and organic matter (OM) content playing a major role. An additional aim is to assess suitability of this species for assessing the toxicity of field-contaminated soils, alone or as part of a battery of soil toxicity tests. It was hypothesized that this species would be a suitable indicator of $\mathrm{Pb}$-polluted field soils. This paper is a part of suite of studies that aimed at linking chemical and biological measures of $\mathrm{Pb}$ bioavailability in shooting range soils with different landscapes, containing different concentrations of $\mathrm{Pb}$ to test their toxicities to different soil animals. To our knowledge, it is novel combining environmental chemistry of naturally aged shooting field soils with bioassays using $P$. peltifer for assessing $\mathrm{Pb}$ polluted soils.

\section{Materials and methods}

\section{Soil sampling}

Six natural soils were taken from three landscapes (F: forest; G: grassland; B: bullet plot) of a shooting field in the Netherlands. Assuming it had similar soil properties without being contaminated, a soccer field soil $(\mathrm{S})$ near the shooting range was sampled as a reference for the survival and reproduction tests. Three artificial soils (R1, R2, R3) were prepared to resemble the shooting field soils in $\mathrm{pH}$ and OM content, based on OECD artificial soil (OECD 1984). R1, the standard artificial soil, was prepared with $10 \%$ finely ground sphagnum peat ( $<1 \mathrm{~mm}), 20 \%$ kaolin clay, and $70 \%$ quartz sand (DW), adjusted with $\mathrm{CaCO}_{3}$ to nominal $\mathrm{pH}_{\mathrm{CaCl}_{2}} 6.0 \pm 0.5$. The other two artificial soils were prepared with peat contents of $5 \%(\mathrm{R} 2)$ or $2.5 \%$ (R3) and $\mathrm{pH}_{\mathrm{CaCl}_{2}}$ adjusted to nominal 3.5 (R2) or 6.5 (R3) with $\mathrm{CaCO}_{3}$ (Luo et al. 2014c). The standard natural LUFA 2.2 soil (LUFA-Speyer, Sp 2121, Germany) was used as an additional control of the performance of the test animals (CK).
Soil analysis

A detailed description of soil analysis and soil characteristics was given by Luo et al. (2014c).

Toxicity tests

Toxicity tests followed the principles of the method described by Van Gestel and Doornekamp (1998), with some modifications. $P$. peltifer were extracted with a Tullgren apparatus from leaf litter sampled in a non-polluted coniferous and oak forest in the Spanderswoud near Hilversum, the Netherlands. A plastic ring (diameter $5 \mathrm{~cm}$, height $3.5 \mathrm{~cm}$ ), closed with gauze (mesh size $1 \mathrm{~mm}$ ) on the bottom which was sealed with a piece of plastic foil, was used as the test container. The top was a closed lid. With the aid of a microscope, ten adult $P$. peltifer were selected randomly from the extracted mites and transferred into each of ten replicate test containers filled with $15 \mathrm{~g}$ test soil moistened to $50 \%$ of the maximum water holding capacity. All exposures were kept in a climate room at $20{ }^{\circ} \mathrm{C}$, $75 \%$ relative humidity and 16/8 h light/dark regime. The water content of the soils was checked once per week by weighing the containers and the mites were fed every 2 weeks by placing $0.1 \mathrm{~g}$ green algae on the soil surface. After 2 weeks, a complete series of five replicate test containers of each test soil were placed in the Tullgren for 2-3 days to extract surviving mites. This procedure was repeated after 12 weeks, to assess survival and the number of juveniles produced. The freeze-dried surviving adult mites were individually digested in a $300 \mu \mathrm{HClO}_{4} / \mathrm{HNO}_{3}$ mixture $(1: 7 \mathrm{v} / \mathrm{v}$; Ultrex grade, Baker) and analysed for body $\mathrm{Pb}$ concentrations using a Perkin Elmer 5100 Atomic Absorption Spectrometer equipped with a graphite furnace assembly. Quality of the analysis was controlled by analyzing certified reference material (Dolt 4 ) and $\mathrm{Pb}$ recoveries were $100 \pm 15 \%$.

\section{Data analysis}

All data were tested for normality (Kolmogorov-Smirnov test) and variance homogeneity. Apart from soil physicochemical properties and toxicity data, all metal concentrations were log-transformed to achieve normal distribution. The data of soils and bioassays in different shooting fields were analyzed by one-way analysis of variance (ANOVA) and a post hoc Tukey HSD test was used to find differences among means. Pearson's correlation coefficients (r) were used to elucidate the latent relationships between toxicity and soil physicochemical properties and (bio) available $\mathrm{Pb}$ concentrations. $\mathrm{EC}_{10}$ and $\mathrm{EC}_{50}$ values for effects on reproduction were estimated 
with a log-logistic model (Haanstra et al. 1985), applying the modification described by Van Brummelen et al. (1996). The bioaccumulation factor (BAF) was calculated as the ratio of the measured $\mathrm{Pb}$ concentrations in the surviving mites and the total $\mathrm{Pb}$ concentrations in the test soils. Statistical analysis was performed using SPSS21.0 for Windows. The significance level was set at $p$ value 0.05 .

\section{Results and discussion}

Lead extractions and soil properties

The forest soils were acidic $\left(\mathrm{pH}_{\mathrm{CaCl}_{2}}\right.$ 3.2-3.5) while the grassland soils were neutral $\left(\mathrm{pH}_{\mathrm{CaCl}_{2}} 6.5-6.8\right)$. The highest total $(2153-2398 \mathrm{mg} / \mathrm{kg})$, water- $(11.7-14.6 \mathrm{mg} / \mathrm{kg})$ and $0.01 \mathrm{M} \mathrm{CaCl}{ }_{2}$-extractable $(279-313 \mathrm{mg} / \mathrm{kg})$ as well as porewater $\mathrm{Pb}$ concentrations (12.9-13.1 mg/L) were observed in forest soils F1 and F3. For a detailed description of soil properties and metal concentrations and a discussion on the influence of soil properties on the availability of $\mathrm{Pb}$ in the test soils it can be referred to our earlier paper (Luo et al. 2014c).

\section{Toxicity tests}

After 2 weeks of exposure, the highest survival of adult $P$. peltifer (80-84\%) was observed in the grassland soils (G1, G3) and forest soil F0, while the soccer field soil had the lowest survival (66 \%) among field soils (Fig. 1a). Except for R1, there was no significant difference in mite survival among field soils, artificial soils and CK $(p>0.05)$. After 12 weeks exposure, the highest survival of $P$. peltifer $(68 \%)$ was found in the soccer field soil (Fig. 1b) while in the other soils survival was significantly lower at $\leq 28 \%$. It seems that $\mathrm{Pb}$ concentrations as high as $2398 \mathrm{mg} / \mathrm{kg}$ DW in the soils had no impact on mite survival after 2 and 12 weeks exposure. The $\mathrm{LC}_{50}$ for the effect for $\mathrm{Pb}$ on the survival of the Oppia nitens after 28-35 days exposure was $6761 \mathrm{mg} / \mathrm{kg}$ DW (Owojori and Siciliano 2012), confirming the relative insensitivity of oribatide mite survival to $\mathrm{Pb}$. Since the optimum $\mathrm{pH}$ for $P$. peltifer was 7.6 , it was classified as alkalophilous and a bioindicator for soil acidification (Van Straalen and Verhoef 1997). However, in our study, the survival of $P$. peltifer in grassland soils, $\mathrm{S}$ and $\mathrm{R} 3$, which had $\mathrm{pH}_{\mathrm{CaCl}_{2}} \geq 6.4$, was not significantly greater than in the acidic soils including all forest soils, B0 and $\mathrm{R} 2$, which had $\mathrm{pH}_{\mathrm{CaCl}_{2}} \leq 3.8$. The absence of a significant relationship between survival and soil $\mathrm{pH}$ after 2 and 12 weeks exposure (Table 1) also suggests that soil $\mathrm{pH}$ had little impact on the mites. Therefore, we could
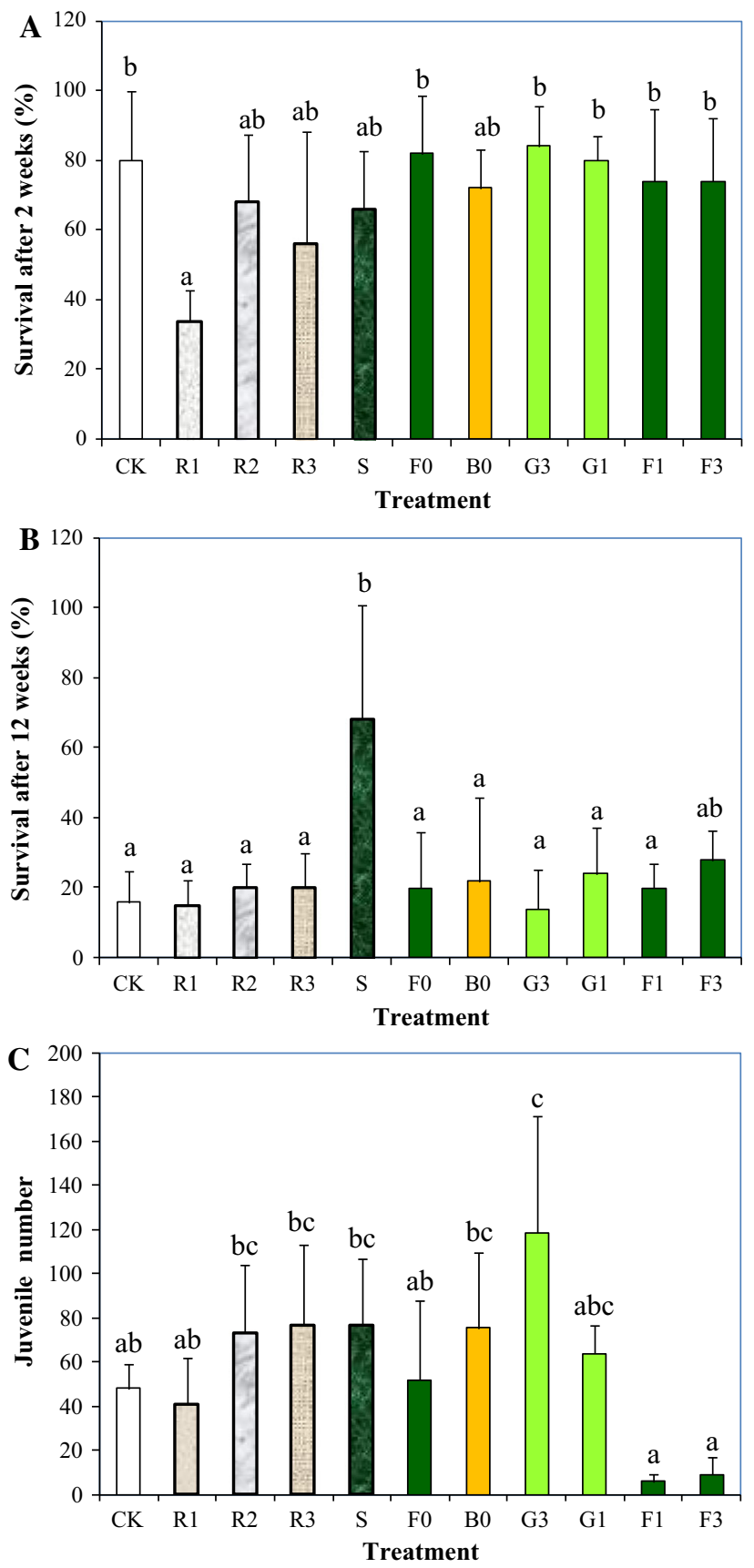

Fig. 1 Survival of Platynothrus peltifer after 2 (a) and 12 (b) weeks and reproduction $(\mathbf{c})$ after 12 weeks exposure to shooting field soils from different landscapes ( $F$ forest, $G$ grassland, $B$ bullet plot) and a reference site ( $S$ soccer field near shooting range) in the Netherlands and in artificial soils (R) as well as a control soil (CK: LUFA 2.2). Columns with the same letter indicate no significant differences at $p>0.05$. Soils are arranged according to increasing total $\mathrm{Pb}$ concentration. See Luo et al. $(2014 a, b, c)$ for the soil codes, soil properties and metal concentrations. Error bars show standard deviation $(n=5)$

conclude that survival of $P$. peltifer may not be a suitable endpoint for assessing $\mathrm{Pb}$-contaminated shooting field soils. 
Table 1 Simple linear correlation coefficients relating the response of Platynothrus peltifer to the physicochemical properties of different shooting range field soils and reference soils

\begin{tabular}{|c|c|c|c|c|}
\hline \multirow{2}{*}{$\begin{array}{l}\text { Soil physicochemical } \\
\text { properties }\end{array}$} & \multicolumn{4}{|c|}{ Simple linear correlation coefficients $(r)$} \\
\hline & $\begin{array}{l}\text { Survival number after } \\
2 \text { weeks }\end{array}$ & $\begin{array}{l}\text { Survival number after } \\
12 \text { weeks }\end{array}$ & $\begin{array}{l}\text { Juvenile number after } \\
12 \text { weeks }\end{array}$ & $\mathrm{Pb}$ in mites \\
\hline WHC & $-0.36 * *$ & $0.50 * *$ & -0.13 & -0.24 \\
\hline $\mathrm{OM}$ & -0.17 & $0.60 * *$ & -0.085 & -0.14 \\
\hline $\mathrm{pH} \mathrm{H}_{2} \mathrm{O}$ & -0.081 & 0.18 & $0.43 * *$ & $-0.34 *$ \\
\hline $\mathrm{pH} 0.01 \mathrm{M} \mathrm{CaCl}_{2}$ & -0.15 & 0.25 & $0.43 * *$ & $-0.40 * *$ \\
\hline DOC & -0.14 & 0.15 & $-0.27 *$ & $-0.34 *$ \\
\hline CEC & -0.15 & $0.49 * *$ & $0.32 *$ & $-0.47 * *$ \\
\hline $\mathrm{Ca}$ & -0.15 & $0.33^{*}$ & $0.38 * *$ & $-0.48 * *$ \\
\hline $\mathrm{Fe}$ & $0.45 * *$ & 0.046 & -0.003 & $0.41 * *$ \\
\hline Clay & $-0.38 * *$ & -0.008 & 0.19 & $-0.57 * *$ \\
\hline Silt & -0.24 & -0.088 & $0.31 *$ & $-0.41 * *$ \\
\hline Sand & $0.34 *$ & 0.040 & -0.25 & $0.53 * *$ \\
\hline $\mathrm{Pb}$-Water & 0.039 & -0.21 & $-0.45 * *$ & $0.88 * *$ \\
\hline $\mathrm{Pb}-0.01 \mathrm{M} \mathrm{CaCl}_{2}$ & 0.10 & -0.10 & $-0.49 * *$ & $0.82 * *$ \\
\hline $\mathrm{Pb}$-pore water & $0.28 *$ & $-0.27^{*}$ & $-0.44 * *$ & $0.92 * *$ \\
\hline Total $\mathrm{Pb}$ & 0.23 & -0.17 & -0.25 & $0.74 * *$ \\
\hline Total Cd & $0.55^{* *}$ & -0.19 & $0.38 * *$ & 0.016 \\
\hline Total Zn & $0.35 * *$ & 0.087 & $0.29 *$ & 0.036 \\
\hline Total $\mathrm{Cu}$ & $0.45 * *$ & 0.029 & 0.21 & 0.26 \\
\hline
\end{tabular}

See Luo et al. (2014a, b, c) for soil properties and metal concentrations and Fig. 1 for the mite responses and internal Pb concentrations in the mites

* Correlation is significant at the 0.05 level (2-tailed)

** Correlation is significant at the 0.01 level (2-tailed)

Platynothrus peltifer reproduction varied greatly, with mean total juvenile numbers ranging from 6.2 to 119 per test jar (Fig. 1c). The most contaminated forest soils F1 and F3 had the lowest juvenile numbers, indicating that both total $\mathrm{Pb}$ concentrations $\geq 2153 \mathrm{mg} / \mathrm{kg}$ DW and low $\mathrm{pH}_{\mathrm{CaCl}_{2}} \leq 3.2$ could significantly inhibit its reproduction. Since there were no significant differences in juvenile numbers between CK and artificial soils (Fig. 1c), low soil $\mathrm{pH}_{\mathrm{CaCl}_{2}}$ (3.8-6.4) and OM contents (2.4-8.8\%) did not significantly impact upon reproduction after 12 weeks exposure. This is confirmed by Owojori and Siciliano (2012) who found no significant difference in reproduction of the mite species $O$. nitens at soil $\mathrm{pH}$ levels of 3.1 and 6.1. Juvenile numbers were significantly and negatively correlated with total, extractable and pore-water $\mathrm{Pb}$ concentrations $(p<0.01)$ (Table 1). $\mathrm{EC}_{50} \mathrm{~s}$ for the effect of $\mathrm{Pb}$ on the reproduction of $P$. peltifer were estimated to be $696,5.5$ and $48.8 \mathrm{mg} / \mathrm{kg}$ DW when related to total, water- and $\mathrm{CaCl}_{2}$-extractable $\mathrm{Pb}$ concentrations, respectively, and $6418 \mu \mathrm{g} / \mathrm{L}$ based on porewater $\mathrm{Pb}$ concentrations. Corresponding $\mathrm{EC}_{10} \mathrm{~s}$ values were $658,2.2$ and $7.2 \mathrm{mg} / \mathrm{kg}$ DW and $3040 \mu \mathrm{g} / \mathrm{L}$, respectively. No confidence intervals could be calculated for any of these $\mathrm{EC}_{\mathrm{x}}$ values.
Compared to survival after 2 and 12 weeks, reproduction is a more sensitive criterion and, thus, a more suitable endpoint for assessing shooting field soils. This conclusion is in agreement with Denneman and Van Straalen (1991), Lebrun and Van Straalen (1995) and Van Straalen et al. (1989). Nevertheless, $P$. peltifer seems more tolerant to $\mathrm{Pb}$ than other species; all $\mathrm{EC}_{50}$ and $\mathrm{EC}_{10}$ values are higher than the ones found for the earthworm Eisenia andrei and the enchytraeid Enchytraeus crypticus, also exposed to the same soils (Luo et al. 2014b, c). Only the springtail Folsomia candida was less sensitive, with $\mathrm{EC}_{50}$ higher than the highest concentration measured in these shooting field soils (Luo et al. 2014a).

\section{Bioaccumulation}

Lead concentrations in $P$. peltifer increased with increasing soil total $\mathrm{Pb}$ concentrations (Fig. 2), and also more or less linearly increased with the administered lead concentration in food (Denneman and Van Straalen 1991). The bioaccumulation factors for $\mathrm{Pb}$ in the mites from most soils of our study were higher than 1 , indicating $P$. peltifer is an accumulator of lead. The bioaccumulation factors of $\mathrm{Pb}$ in 


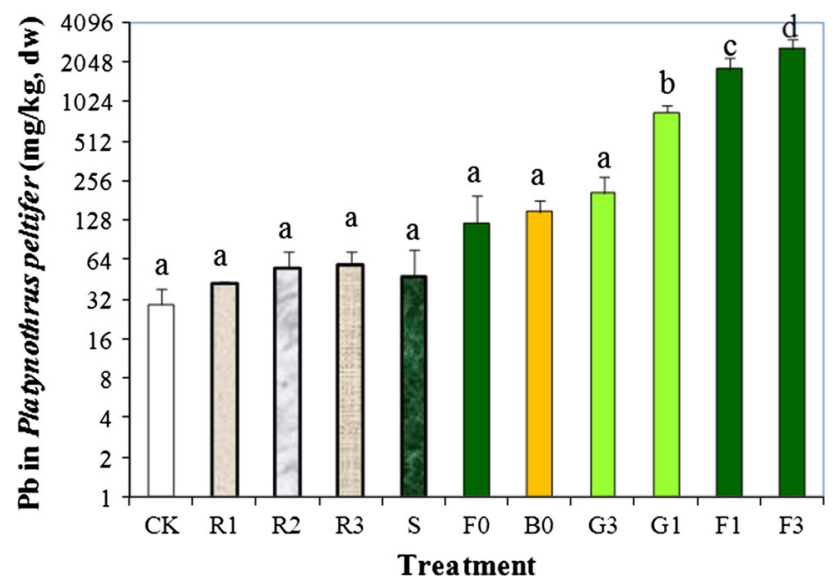

Fig. 2 Tissue $\mathrm{Pb}$ concentrations in Platynothrus peltifer after 12 weeks exposure to shooting field soils from different landscapes ( $F$ forest, $G$ grassland, $B$ bullet plot) and a reference site $(S$ soccer field near shooting range) in the Netherlands and in artificial soils (R) as well as a control (CK: LUFA 2.2). Columns with the same letter indicate no significant differences at $p>0.05$. Soils are arranged according to increasing total $\mathrm{Pb}$ concentration. See Luo et al. (2014a, b, c) for the soil codes, soil properties and metal concentrations. Error bars show standard deviation $(n=5)$

$P$. peltifer in our study were obviously higher than those in $P$. peltifer collected from litter layers of forest and zinc smelter in the Netherlands (Janssen and Hogervorst 1993). $\mathrm{Pb}$ concentrations in the mites exposed to the three most $\mathrm{Pb}$ polluted soils (G1, F1, F3) were significantly higher than those kept in the other soils. This further indicates that bioaccumulation of $\mathrm{Pb}$ was significant at soil $\mathrm{Pb}$ concentrations $\geq 656 \mathrm{mg} / \mathrm{kg}$ DW. The high concentrations of $\mathrm{Pb}$ in $P$. peltifer exposed to the forest soils F1 and F3 may be explained by the high porewater $\mathrm{Pb}$ concentrations, which confirms exposure is mainly from the pore water (Van Gestel et al. 1995). Since the availability of $\mathrm{Pb}$ increases with reduced $\mathrm{pH}$ (Alexander 2000), the high bioavailability of $\mathrm{Pb}$ in the forest soils was also due to their low $\mathrm{pH}$. $\mathrm{Pb}$ concentrations in the mites were significantly and positively correlated with total and extractable $\mathrm{Pb}$ concentrations in the soils and with porewater $\mathrm{Pb}$ concentrations, but also affected by soil texture, $\mathrm{Fe}$ and $\mathrm{Ca}$ concentrations, CEC and soil $\mathrm{pH}_{\mathrm{CaCl}_{2}}(p<0.01)$ (Table 1).

\section{Conclusion}

Survival of $P$. peltifer was less sensitive to $\mathrm{Pb}$-contaminated shooting range soils than reproduction, making the latter a more suitable endpoint for assessing contaminated field soils. Reproduction and $\mathrm{Pb}$ concentrations in the mites significantly correlated with total, extractable and porewater $\mathrm{Pb}$ concentrations in the soils. $P$. peltifer however, seems more tolerant to $\mathrm{Pb}$ than other species, with effects on reproduction only occurring in acidic forest soils $\left(\mathrm{pH}_{\mathrm{CaCl}_{2}} \leq 3.5\right.$ ) with $\mathrm{Pb}$ concentrations $\geq 2153 \mathrm{mg} / \mathrm{kg}$ DW. As a consequence, this species seems less suitable for assessing the toxicity of $\mathrm{Pb}$ contaminated field soils.

Acknowledgments This Project was supported by a visitor's Grant (Number 040.11.222) from The Netherlands Science Foundation (NWO) and the National Natural Science Foundation of China under Grant No. 41271502.

Conflict of interest The authors declare that they have no conflict of interest.

Open Access This article is distributed under the terms of the Creative Commons Attribution License which permits any use, distribution, and reproduction in any medium, provided the original author(s) and the source are credited.

\section{References}

Alexander M (2000) Aging, bioavailability, and overestimation of risk from environmental pollutants. Environ Sci Technol 34: $4259-4265$

Allen H (2002) Bioavailability of metals in terrestrial ecosystems: importance of partitioning for bioavailability to invertebrates, microbes, and plants. SETAC, Pensacola

Chen M, Daroub SH, Ma LQ, Harris WG, Cao XD (2002) Characterization of lead in soils of a rifle/pistol shooting range in central Florida, USA. Soil Sediment Contam 11:1-17

Crossley DA Jr (1977) The roles of terrestrial saprophagous arthropods in forest soils: current status of concepts. In: Mattson WJ (ed) The role of arthropods in forest ecosystems. Springer, Heidelberg, pp 49-56

Denneman CAJ, Van Straalen NM (1991) The toxicity of lead and copper in reproduction tests using the oribatid mite Platynothrus peltifer. Pedobiologia 35:305-311

Haanstra L, Doelman P, Oude Voshaar JH (1985) The use of sigmoidal dose response curves in soil ecotoxicological research. Plant Soil 84:293-297

Hopkin SP (1989) Ecophysiology of metals in terrestrial invertebrates. Elsevier, London

Janssen MPM, Hogervorst RF (1993) Metal accumulation in soil arthropods in relation to micro-nutrients. Environ Pollut 79:181-189

Krantz G, Walter D (2009) A manual of acarology, 3rd. Texas Tech University Press, Lubbock

Lanno RP (2003) Contaminated soils: from soil chemical interactions to ecosystem management. Society of Environmental Toxicology and Chemistry (SETAC), Pensacola

Lebrun P (1979) Soil mite community diversity. In: Rodriguez JG (ed) Recent advances in acarology, vol 1. Academic Press, New York, pp 603-613

Lebrun P, Van Straalen NM (1995) Oribatid mites: prospects for their use in ecotoxicology. Exp Appl Acarol 19:361-379

Luo W, Verweij RA, Van Gestel CAM (2014a) Assessment of the bioavailability and toxicity of lead polluted soils using a combination of chemical approaches and bioassays with the collembolan Folsomia candida. J Hazard Mater 280:524-530

Luo W, Verweij RA, van Gestel CAM (2014b) Contribution of soil properties of shooting fields to lead biovailability and toxicity to Enchytraeus crypticus. Soil Biol Biochem 76:235-241

Luo W, Verweij RA, van Gestel CAM (2014c) Determining the bioavailability and toxicity of lead contamination to earthworms 
requires using a combination of physicochemical and biological methods. Environ Pollut 185:1-9

Manninen S, Tanskanen N (1993) Transfer of lead from shotgun pellets to humus and 3 plant-species in a finish shooting range. Arch Environ Con Tox 24:410-414

Ming H, He W, Lamb DT, Megharaj M, Naidu R (2012) Bioavailability of lead in contaminated soil depends on the nature of bioreceptor. Ecotox Environ Safe 78:344-350

Murray K, Bazzi A, Carter C, Ehlert A, Harris A, Kopec M, Richardson J, Sokol H (1997) Distribution and mobility of lead in soils at an outdoor shooting range. J Soil Contam 6:79-93

OECD (1984) Guidelines for the testing of chemicals no. 207. Earthworm acute toxicity. Organization for Economic Cooperation and Development, Paris

Owojori OJ, Siciliano SD (2012) Accumulation and toxicity of metals (copper, zinc, cadmium, and lead) and organic compounds (geraniol and benzo(a)pyrene) in the oribatid mite Oppia nitens. Environ Toxicol Chem 31:1639-1648

Peijnenburg W, Baerselman R, De Groot AC, Jager T, Posthuma L, Van Veen RPM (1999) Relating environmental availability to bioavailability: soil-type-dependent metal accumulation in the oligochaete Eisenia andrei. Ecotox Environ Safe 44:294-310

Rooney CP, McLaren RG, Cresswell RJ (1999) Distribution and phytoavailability of lead in a soil contaminated with lead shot. Water Air Soil Pollut 116:535-548
Scheuhammer AM, Norris SL (1995) A review of the environmental impacts of lead shotshell ammunition and lead fishing weights in Canada. Can Wildlife Serv 88:1-52

Van Brummelen TC, Van Gestel CAM, Verweij RA (1996) Longterm toxicity of five polycyclic aromatic hydrocarbons to the terrestrial isopods Oniscus asellus and Porcellio scaber. Environ Toxicol Chem 15:1199-1210

Van Gestel CAM, Doornekamp A (1998) Tests on the oribatid mite Platynothrus peltifer. In: Løkke H, van Gestel CAM (eds) Handbook of soil invertebrate toxicity tests. Wiley, Chichester, pp 113-130

Van Gestel CAM, Van Hekezen J, Bot J, Doornekamp A (1995) Development of a standardized soil ecotoxicity test with Platynothrus peltifer (Acari: Oribatida), using copper as a reference chemical. In: Van den Brink WJ, Bosman R, Arendt F (eds) Contaminated Soil '95. Kluwer Academic Publishers, Dordrecht, pp 611-612

Van Straalen NM, Verhoef HA (1997) The development of a bioindicator system for soil acidity based on arthropod $\mathrm{pH}$ preferences. J Appl Ecol 34:217-232

Van Straalen NM, Schobben JH, de Goede RG (1989) Population consequences of cadmium toxicity in soil microarthropods. Ecotox Environ Safe 17:190-204 